\title{
Generation of electric power and air conditioning by cogeneration: a proposal for energy saving
}

\author{
Producción de energía eléctrica y aire acondicionado por cogeneración: \\ Una propuesta de ahorro de energía \\ Produção de energia elétrica e ar condicionado por cogeração: Uma \\ proposta de economia de energia
}

Fecha de recepción: 8 de junio de 2018

Iván Vera-Romero*

Fecha de aprobación: 19 de agosto de 2018

\section{Abstract}

This paper presents the results of a case study carried out in a warehouse, and, in particular, the technical data obtained from field visits and a proposal for energy saving. The proposal entails incorporating a cogeneration system based on a motor generator (400 kWe ISO) to produce electrical energy, and an absorption cooling system (75 TR) that uses residual heat to generate air-conditioning. The absorption chiller consumed $54 \%$ less energy than the conventional air-conditioning system. Moreover, the produced energy can supply the plant's total consumption, in addition to offering an excess of $57,312 \mathrm{kWh}$ per month, which was reflected in the analysis of energy for sale to users with a high domestic consumption rate (DAC, for its Spanish acronym). The proposal's total investment is USD 1,091,258, with a net monthly savings of USD 30,901, and an investment payback period of 2.9 years, which indicates the viability of this project according to its energy characteristics, notwithstanding that it is for a service provider company.

Keywords: absorption cooling; cogeneration; cost-benefit analysis; energetic consulting; energy savings.

\section{Resumen}

Este trabajo es resultado de un estudio de caso realizado en una bodega. Se muestran en él los datos técnicos obtenidos a partir de la visita de campo y una propuesta energética. La propuesta consta de la incorporación de un sistema de cogeneración basado en un motogenerador (400 kWe ISO) para producir energía eléctrica y de un sistema de refrigeración por absorción ( $75 \mathrm{TR})$ que aproveche el calor residual para generar aire acondicionado. Se observó que el chiller de absorción consume $54 \%$ menos energía que el sistema convencional de aire acondicionado empleado. Por otra parte, la energía producida abastece el total del consumo de la planta, además de ofrecer un excedente de 57,312 kWh por mes, el cual se tomó en el análisis como energía de venta a usuarios con tarifa doméstica de alto consumo (DAC). La inversión total de la propuesta es de 1091258 USD, con un ahorro neto mensual de 30901 USD y un tiempo de recuperación de la inversión de 2.9 años, lo que indica la viabilidad de este proyecto de acuerdo con sus características energéticas, a pesar de tratarse de una empresa que brinda servicios.

* M. Sc. Universidad de la Ciénega del Estado de Michoacán de Ocampo (Michoacán, México). ivera@ucienegam.edu.mx. ORCID: 00000003-1771-6630. 
Palabras clave: ahorro de energía; análisis costo-beneficio; cogeneración; consultoría energética; refrigeración por absorción.

\section{Resumo}

Este trabalho é resultado de um estudo de caso realizado em um porão. Mostram-se neste estudo os dados técnicos obtidos a partir da visita de campo e uma proposta energética. A proposta consta da incorporação de um sistema de cogeração baseado em um motogerador (400 kWe ISO) para produzir energia elétrica e de um sistema de refrigeração por absorção (75 TR) que aproveite o calor residual para gerar ar condicionado. Observou-se que o chiller de absorção consome 54\% menos energia que o sistema convencional de ar condicionado empregado. Por outra parte, a energia produzida abastece o total do consumo da usina, além de oferecer um excedente de 57,312 $\mathrm{kWh}$ por mês, o qual se tomou na análise como energia de venda a usuários com tarifa doméstica de alto consumo (DAC). A inversão total da proposta é de 1091258 USD, com uma economia líquida mensal de 30901 USD e um tempo de recuperação da inversão de 2.9 anos, o que indica a viabilidade deste projeto de acordo com suas características energéticas, apesar de tratar-se de uma empresa que oferece serviços.

Palavras chave: economia de energia; análise custo-benefício; cogeração; consultoria energética; refrigeração por absorção.

\section{Cómo citar este artículo:}

I. Vera-Romero, "Generation of electric power and air conditioning by cogeneration: a proposal for energy saving," Revista Facultad de Ingenieria, vol. 27 (49), pp. 35-47, Sep. 2018. 


\section{INTRODUCTION}

The need of using technology to increase energy efficiency in industrial processes and apply energy savings techniques to decrease production costs throughout the entire industry is currently a topic of great importance [1]. Reducing production costs improves the profitability of companies [2]; therefore, techniques for increasing efficiency and energy savings are not only employed or demanded by industries that produce goods [3], but also by companies that offer different types of services [4].

Applying energy savings strategies such as motion detectors, infra-red technology, operating time programs, energy-efficient lighting, fuel changes, burner changes, modernized auxiliary equipment, and renovated equipment, among others is fundamental to bring about significant savings, mainly in thermal and electrical energy bills. However, other alternatives can be studied and applied; for example, using different energy generation schemes by implementing power cycles and systems [5].

Companies aim at becoming more competitive in the international market with energy savings and increased energy efficiency, which create a demand for better quality products at lower costs on an increasing basis. Therefore, applying these engineering techniques, seek to obtain an economic and ecological benefit with high operational functionality that minimizes the risks for personnel.

Here, we present the results from a case study conducted in a warehouse with the aim of offering an energy solution or alternative [6]. To conduct this study, we measured, in the field and with specialized instruments, the energy consumption of the auxiliary process equipment, and checked the operation and performance of air-conditioning and lighting equipment. The objective was to understand the equipment operation and performance to quantify their impact on energy costs, and hence, create a proposal for increasing energy efficiency that would result in economic savings.

\section{Methodology}

The warehouse historical monthly energy consumption records were gathered from at least 12 months of bills issued by the Mexico's Federal Electricity Commission (Comisión Federal de Electricidad, CFE). This guaranteed that the data used in the analysis were real and objective. The data included the rate type, the connected load (CC, for its initials in Spanish), the contract demand (DC, for its initials in Spanish), the maximum demands, the billable demand (DF, for its initials in Spanish), the power factor (FP, for its initials in Spanish), the load factor (FC, for its initials in Spanish), the consumption per period, and in total, the average price of the energy consumed ( $\mathrm{Pm}$, for its initials in Spanish) and the discounts or penalties according to the power factor, among others (www.cfe.gob.mx), as well as the consumption of water and fuel.

Technical visits to each area and department of the warehouse were conducted to develop a detailed field survey. The survey included identifying all types of tubing (water, fuel, air-conditioning, etc.) and the type and quantity of lights, as well as gathering technical plate information from all the operating equipment and recording their physical operating parameters (e.g., temperature, pressure, capacity, flow, electrical parameters). Likewise, operators were visited to collect variables that could not be obtained directly from physical measurements, such as usage habits, maintenance hours, and considerations beyond maintenance controls, among others. This information was used to identify various opportunities for increasing efficiency and saving energy and improving operating programs and maintenance with the systems and equipment [7].

\section{RESULTS}

From the field surveys, we found that implementing a cogeneration system in the warehouse represents a savings opportunity $[8,9]$. This system would operate with a motor generator to produce electrical energy and an absorption cooling system to provide airconditioning $[10,11]$. The current energy performance conditions of the entire warehouse are described below.

\section{A. Current situation}

The plant has a contract with CFE for a mediumvoltage rate (HM) with a supply of $13,200 \mathrm{~V}$. It has two $350 \mathrm{~kW}$ generators, which generate electrical energy during peak hours and serve as backup equipment in case of outages. Table 1 shows the electrical energy consumption and maximum demands of the studied plant. 
TABLE 1

ELECTRICITY CONSUMPTION AND DEMANDS

\begin{tabular}{lrrrrrrrr}
\hline & \multicolumn{3}{c}{ Demand (kW) } & \multicolumn{5}{c}{ Consumption (kWh) } \\
\hline Month & Base & Intermediate & Peak & Billable & Base & Intermediate & Peak & Total \\
\hline January & 465 & 484 & 400 & 426 & 56,794 & 127,546 & 31,600 & 215,940 \\
February & 466 & 444 & 404 & 420 & 51,498 & 117,076 & 29,592 & 198,166 \\
March & 473 & 507 & 475 & 485 & 55,370 & 125,421 & 31,373 & 212,164 \\
April & 594 & 497 & 546 & 554 & 55,958 & 135,941 & 54,838 & 246,737 \\
May & 621 & 519 & 569 & 577 & 71,170 & 149,416 & 27,558 & 248,144 \\
June & 642 & 547 & 494 & 525 & 108,011 & 120,388 & 13,258 & 241,658 \\
July & 635 & 512 & 565 & 576 & 64,651 & 165,645 & 27,116 & 257,412 \\
August & 620 & 495 & 548 & 560 & 70,316 & 160,207 & 26,272 & 256,795 \\
September & 583 & 515 & 564 & 567 & 65,022 & 150,573 & 26,474 & 242,070 \\
October & 604 & 470 & 519 & 532 & 61,034 & 136,102 & 53,500 & 250,636 \\
November & 498 & 567 & 439 & 478 & 54,874 & 134,521 & 33,677 & 223,072 \\
December & 429 & 521 & 413 & 446 & 49,695 & 140,200 & 34,741 & 224,636 \\
\hline Minimum & 429 & 444 & 400 & 420 & 49,695 & 117,076 & 13,258 & 198,166 \\
Maximum & 642 & 567 & 569 & 577 & 108,011 & 165,645 & 54,838 & 257,412 \\
Average & 553 & 506 & 495 & 512 & 63,699 & 138,586 & 32,500 & 234,786 \\
\hline
\end{tabular}

The plant also has 14 package units of 25 tons of refrigeration (TR) each that supply air-conditioning to the entire warehouse; this is mainly used during summer when ambient temperatures increase. This equipment is activated in staggered phases throughout the day. The first four equipment packages are activated at 6:00 a.m., then, four more are activated at 12 p.m., and the six remaining are turned on at 2:00 p.m. Seven of them are turned off at 8:00 p.m., and the rest, at 11:00 p.m. (Fig. 1). This takes place during the eight-month season that is considered to have high ambient temperatures, which lasts from March to October. All the equipment operates for an average of 10.6 hours a day; however, the first four equipment units operate a total of 17 hours a day, experiencing greater wear, which reduces their lifespan compared to the rest of the equipment. Regarding the lights, the evaluation showed that they are in good condition and do not need changes or modifications.

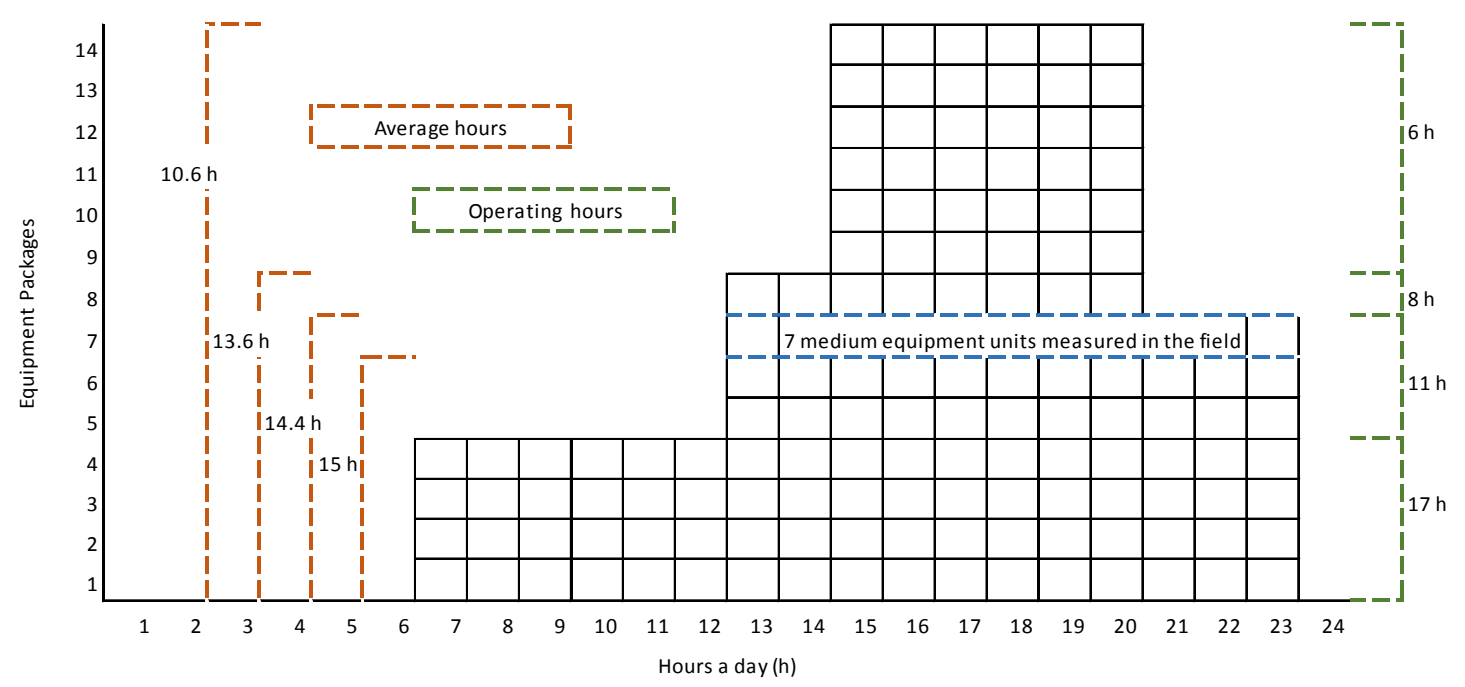

Fig. 1. Staggered operation of the 14 equipment packages. 
The air-conditioning equipment is distributed throughout the entire area of the warehouse, offering adequate comfort. The operation of the first seven air conditioning units was measured in the field (Table 2 and Fig. 2); subsequently, this information was used for extrapolating energy consumption for the rest of the equipment packages. The first seven equipment packages that are turned on during the day are used $75 \%$ more than the others.

TABle 2

TESTS AND FIELD MEASUREMENTS OF THE SEVEN EQUIPMENT PACKAGES

\begin{tabular}{ccccc} 
Equipment & & Amp & $\mathbf{V}$ & $\mathbf{k W}$ Total \\
\hline 1 & EP-14 & 25.3 & 491 & 32.1 \\
2 & EP-09 & 45.4 & 487 & 32 \\
3 & EP-05 & 30.7 & 493 & 33.4 \\
4 & EP-08 & 29.1 & 488 & 36.8 \\
5 & EP-12 & 46.3 & 484 & 32 \\
6 & EP-11 & 53.1 & 489 & 33.6 \\
7 & EP-01 & 46.7 & 493 & 32 \\
\hline Total & & & & 231.9 \\
Average & & & & 33.13 \\
\hline
\end{tabular}

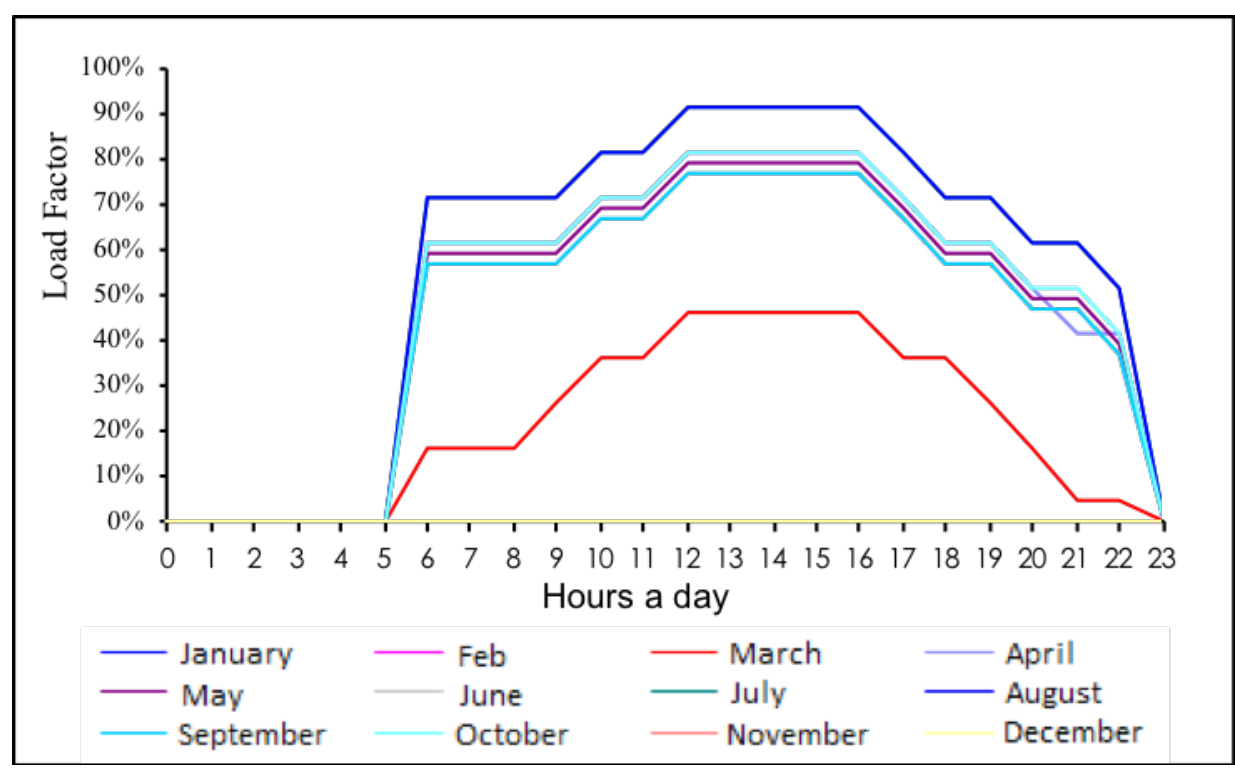

FIG. 2. Load curve of the air-conditioning equipment for a full year.

Table 3 reports the total consumption of the 14 equipment packages and their load percentage, in relation to the total consumption of the warehouse. Moreover, Table 4 shows that the consumption of the first seven equipment units that are turned on (the ones monitored in the field) represent approximately $80 \%$ of the energy consumption of all the air conditioning equipment. 
TABLE 3

AIR-CONDITIONING ENERGY CONSUMPTION FOR THE 14 EQUIPMENT PACKAGES

\begin{tabular}{lrrr}
\hline Month & $\begin{array}{l}\text { TOTAL } \\
\text { Energy } \\
(\mathbf{k W h})\end{array}$ & $\begin{array}{c}\text { Energy consumed } \\
\text { 14 equipment packages } \\
\text { (kWh) }\end{array}$ & $\begin{array}{c}\text { Load } \\
\text { percentage } \\
(\%)\end{array}$ \\
\hline January & 215,940 & --- & --- \\
February & 198,166 & --- & -- \\
March & 212,164 & 85,030 & 40 \\
April & 246,737 & 131,455 & 53 \\
May & 248,144 & 133,615 & 54 \\
June & 241,658 & 124,970 & 52 \\
July & 257,412 & 153,724 & 60 \\
August & 256,795 & 154,041 & 60 \\
September & 242,070 & 125,339 & 52 \\
October & 250,636 & 136,749 & 55 \\
November & 223,072 & --- & --- \\
December & 224,636 & --- & -- \\
\hline Minimum & 198,166 & 85,030 & 40 \\
Maximum & 257,412 & 154,041 & 60 \\
Average & 234,786 & 130,615 & 53 \\
\hline
\end{tabular}

TABLE 4

AIR-CONDITIONING ENERGY CONSUMPTION FOR THE FIRST SEVEN EQUIPMENT PACKAGES TO BE

\begin{tabular}{lcrr}
\multicolumn{4}{c}{ TURNED ON } \\
\hline Month & $\begin{array}{l}\text { TOTAL } \\
\text { Energy } \\
\text { (kWh) }\end{array}$ & $\begin{array}{c}\text { Energy consumed } \\
\text { 7 equipment packages } \\
\text { (kWh) }\end{array}$ & $\begin{array}{c}\text { Load } \\
\text { percentage } \\
\mathbf{( \% )}\end{array}$ \\
\hline January & 215,940 & --- & -- \\
February & 198,166 & -- & -- \\
March & 212,164 & 68,378 & 32 \\
April & 246,737 & 105,711 & 43 \\
May & 248,144 & 107,449 & 43 \\
June & 241,658 & 100,496 & 42 \\
July & 257,412 & 123,619 & 48 \\
August & 256,795 & 123,874 & 48 \\
September & 242,070 & 100,793 & 42 \\
October & 250,636 & 109,968 & 44 \\
November & 223,072 & --- & -- \\
December & 224,636 & --- & -- \\
\hline Minimum & 198,166 & 68,378 & 32 \\
Maximum & 257,412 & 123,874 & 48 \\
Average & 234,786 & 105,036 & 43 \\
\hline
\end{tabular}

The studied company uses natural gas, with an average calorific value of $36,421 \mathrm{~kJ} \mathrm{~m}^{-3}$ and a supply pressure of $2 \mathrm{~kg} \mathrm{~cm}^{-2}$. Natural gas is used at these rates in different areas of the warehouse (Table 5). 
TABLE 5

\section{FUEL CONSUMPTION}

\begin{tabular}{lr}
\hline Month & $\mathbf{G N}\left(\mathbf{m}^{3}\right)$ \\
\hline January & 5,527 \\
February & 6,601 \\
March & 6,061 \\
April & 5,854 \\
May & 5,979 \\
June & 5,000 \\
July & 5,692 \\
August & 5,268 \\
September & 4,719 \\
October & 5,102 \\
November & 4,822 \\
December & 4,376 \\
\hline Minimum & 4,376 \\
Maximum & 6,601 \\
Average & 5,417 \\
\hline
\end{tabular}

\section{B. Proposal}

The proposal entails generating electrical energy with a motor generator powered by natural gas (Tables 6 and 7) and, at the same time, using the residual heat from gas exhaust and exhaust sleeves to produce airconditioning with an absorption cooling system of lithium bromide-water $\left(\mathrm{H}_{2} \mathrm{O}-\mathrm{LiBr}\right)$ as a working fluid, presenting a cooling capacity of 75 TR (commercial equipment).

\section{TABLE 6}

CHARACTERISTICS OF A COMMERCIAL MOTOR

\begin{tabular}{lrl}
\multicolumn{3}{c}{ GENERATOR } \\
\hline Output power & 400 & $\mathrm{kWe}$ \\
Electrical efficiency & 41.4 & $\%$ \\
Thermal efficiency & 46.5 & $\%$ \\
Cogeneration & & \\
efficiency & 87.9 & $\%$ \\
Heat rate & 8,298 & $\begin{array}{l}\mathrm{BTU} \\
\mathrm{kWh}^{-1}\end{array}$ \\
$\begin{array}{l}\text { Cogeneration heat } \\
\text { rate }\end{array}$ & 3,914 & $\begin{array}{l}\mathrm{BTU}^{-1} \\
\text { Fuel type }\end{array}$ \\
\hline
\end{tabular}

The amount of available residual heat is 448 thermal $\mathrm{kW}$. This power is reduced when considering the cooling coefficient performance (COP) of the absorption system (0.6 in this case), which will help substituting three equipment packages.

\section{TABLE 7}

INITIAL PARAMETERS FOR THE COGENERATION SYSTEM ANALYSIS

\begin{tabular}{|c|c|c|c|c|c|c|c|c|}
\hline $\begin{array}{c}\text { Average } \\
\text { room } \\
\text { temperature } \\
{ }^{\circ} \mathbf{C} \\
\end{array}$ & $\begin{array}{c}\text { Average } \\
\text { relative } \\
\text { humidity } \\
(\%)\end{array}$ & $\begin{array}{l}\text { Estimated } \\
\text { power } \\
(\mathrm{kWe})\end{array}$ & $\begin{array}{c}\text { Average fuel } \\
\text { consumption } \\
\text { (GJ) }\end{array}$ & $\begin{array}{c}\text { Motor } \\
\text { generator } \\
\text { heat rate } \\
\left(\text { BTU } \mathbf{k W h}^{-1}\right)\end{array}$ & $\begin{array}{c}\text { Cogeneration } \\
\text { heat rate } \\
\left(\text { BTU } \mathbf{k W h}^{-1}\right)\end{array}$ & TR & FC & $\mathbf{k W t}$ \\
\hline 23.4 & 60 & 400 & 2.316 & 8,298 & 3,914 & 75 & $95 \%$ & 448 \\
\hline
\end{tabular}

The system will require a new supply system of ice water to provide air-conditioning through a blower coil, which will substitute the three equipment packages of 25 TR each. To achieve this, it will be necessary to install ice water pumps, a condensing system, and a cooling tower. The three equipment packages to be substituted are three of the first four units that are turned on at 6:00 a.m. and turned off at 11:00 p.m. every day during the eight months that the warehouse uses air-conditioning.
By implementing this cogeneration system, an average monthly electrical energy savings of 234,786 $\mathrm{kWh}$ will be achieved with the additional benefit of $29,804 \mathrm{kWh}$ in surplus energy per month, which could be exported at the DAC rate at the cost of $10 \%$ less than its billing price. In addition, an average monthly savings of $372 \mathrm{~kW}$ for billable demand would be obtained (Fig. 3). Concurrently, there will be a $155 \mathrm{~m}^{3}$ increase of ice water in the cooling tower per month with the installation of the absorption chiller. Table 8 shows the peripheral equipment consumption for each air-conditioning system along with the savings that would be gained thanks to the change in technology. 


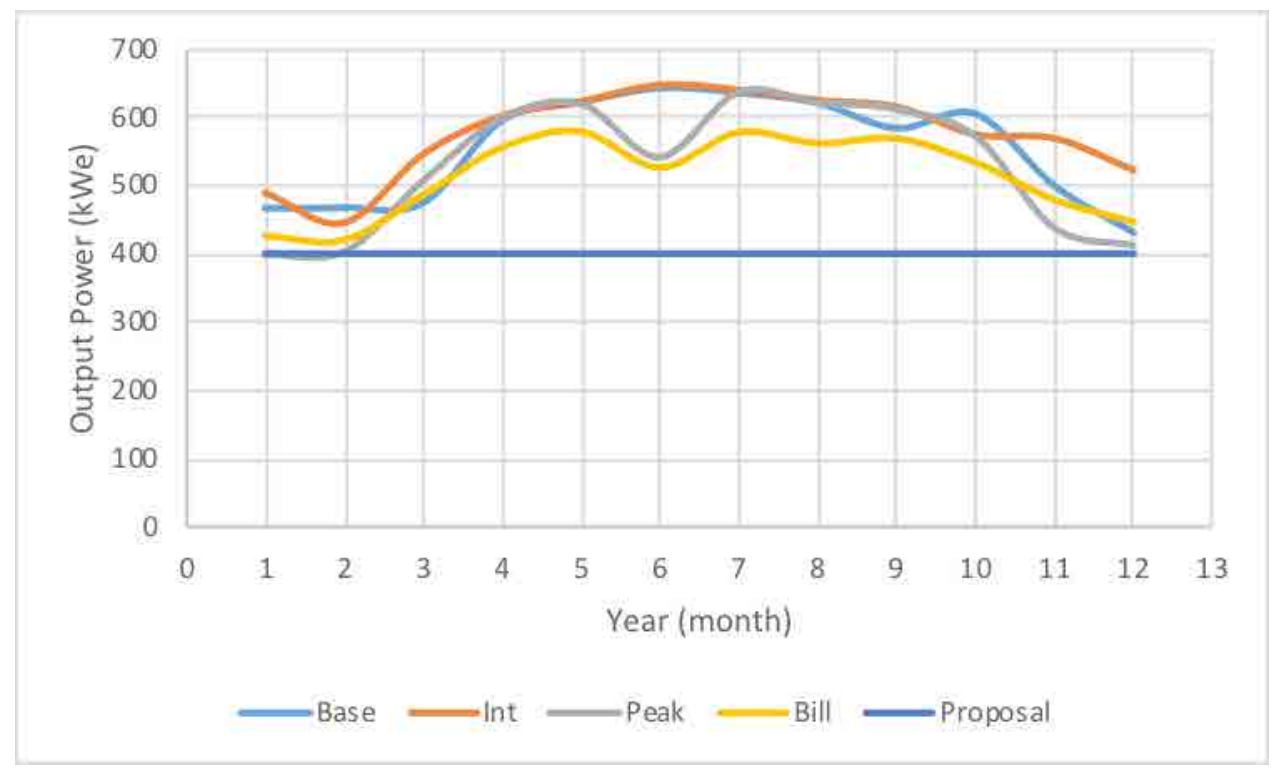

Fig. 3. Behavior of demands throughout the year.

TABle 8

COMPARISON OF AIR-CONDITIONING EQUIPMENT CONSUMPTION AND ENERGY SAVINGS Proposed absorption chiller consumption (kWh) Current consumption of three
$\begin{gathered}\text { Blower } \\ \text { consumption }\end{gathered}$ $\begin{gathered}\text { Compressor } \\ \text { consumption }\end{gathered}$ $\begin{array}{cc}\begin{array}{c}\text { Condenser } \\ \text { fan }\end{array} & \begin{array}{c}\text { Current } \\ \text { equipment }\end{array} \\ \text { consumption } & \begin{array}{c}\text { equmsumption } \\ \text { consument packages }(\mathrm{kWh})\end{array}\end{array}$ Percentage of savings for peripheral equipment

\begin{tabular}{|c|c|c|c|c|c|c|c|c|c|c|c|}
\hline & & & & & & & & & \\
\hline January & --- & --- & --- & --- & --- & --- & --- & --- & --- & & --- \\
\hline February & --- & --- & --- & --- & --- & --- & --- & --- & --- & & --- \\
\hline March & 2,240 & 16,033 & 2,240 & 3,285 & 23,798 & 9,808 & 22,541 & 863 & 33,212 & $28 \%$ & \\
\hline April & 2,168 & 15,516 & 2,168 & 3,179 & 23,030 & 15,163 & 34,848 & 1,335 & 51,346 & $55 \%$ & \\
\hline May & 2,240 & 16,033 & 2,240 & 3,285 & 23,798 & 15,413 & 35,421 & 1,356 & 52,189 & $54 \%$ & \\
\hline June & 2,168 & 15,516 & 2,168 & 3,179 & 23,030 & 14,446 & 33,128 & 1,269 & 48,813 & $53 \%$ & \\
\hline July & 2,240 & 16,033 & 2,240 & 3,285 & 23,798 & 17,732 & 40,751 & 1,561 & 60,043 & $60 \%$ & \\
\hline August & 2,240 & 16,033 & 2,240 & 3,285 & 23,798 & 17,768 & 40,835 & 1,563 & 60,168 & $60 \%$ & \\
\hline September & 2,168 & 15,516 & 2,168 & 3,179 & 23,030 & 14,458 & 33,227 & 1,272 & 48,957 & $53 \%$ & \\
\hline October & 2,240 & 16,033 & 2,240 & 3,285 & 23,798 & 15,774 & 36,251 & 1,388 & 53,413 & $55 \%$ & \\
\hline November & --- & --- & --- & --- & --- & --- & --- & --- & --- & & --- \\
\hline December & --- & --- & --- & --- & --- & --- & --- & --- & --- & & --- \\
\hline Minimum & 2,168 & 15,516 & 2,168 & 3,179 & 23,030 & 9,808 & 22,541 & 863 & 33,212 & $31 \%$ & \\
\hline Maximum & 2,240 & 16,033 & 2,240 & 3,285 & 23,798 & 17,768 & 40,835 & 1,563 & 60,168 & $60 \%$ & \\
\hline Average & 2,213 & 15,839 & 2,213 & 3,245 & 23,510 & 15,070 & 34,625 & 1,326 & 51,018 & $54 \%$ & \\
\hline TOTAL & 17,703 & 126,716 & 17,703 & 25,962 & 188,080 & 120,563 & 277,001 & 10,607 & 408,141 & & \\
\hline
\end{tabular}

The final evaluation considered the complete installation of the cogeneration system, which includes the motor generator, the ice water and condensed water pumping, the transfer tables, and the booths. Water from the powering system and replacement water will be used for evaporation in the cooling tower. A thorough civil engineering project is being contemplated to install the main and peripheral equipment, including the labor needed to position the tables, the generator equipment, and the air-conditioning equipment, and to remove the existing equipment. Also, adaptations and installations for supplying natural gas to the new generator equipment have been contemplated. Fig. 4 shows the conceptual arrangement of the proposed cogeneration system. 


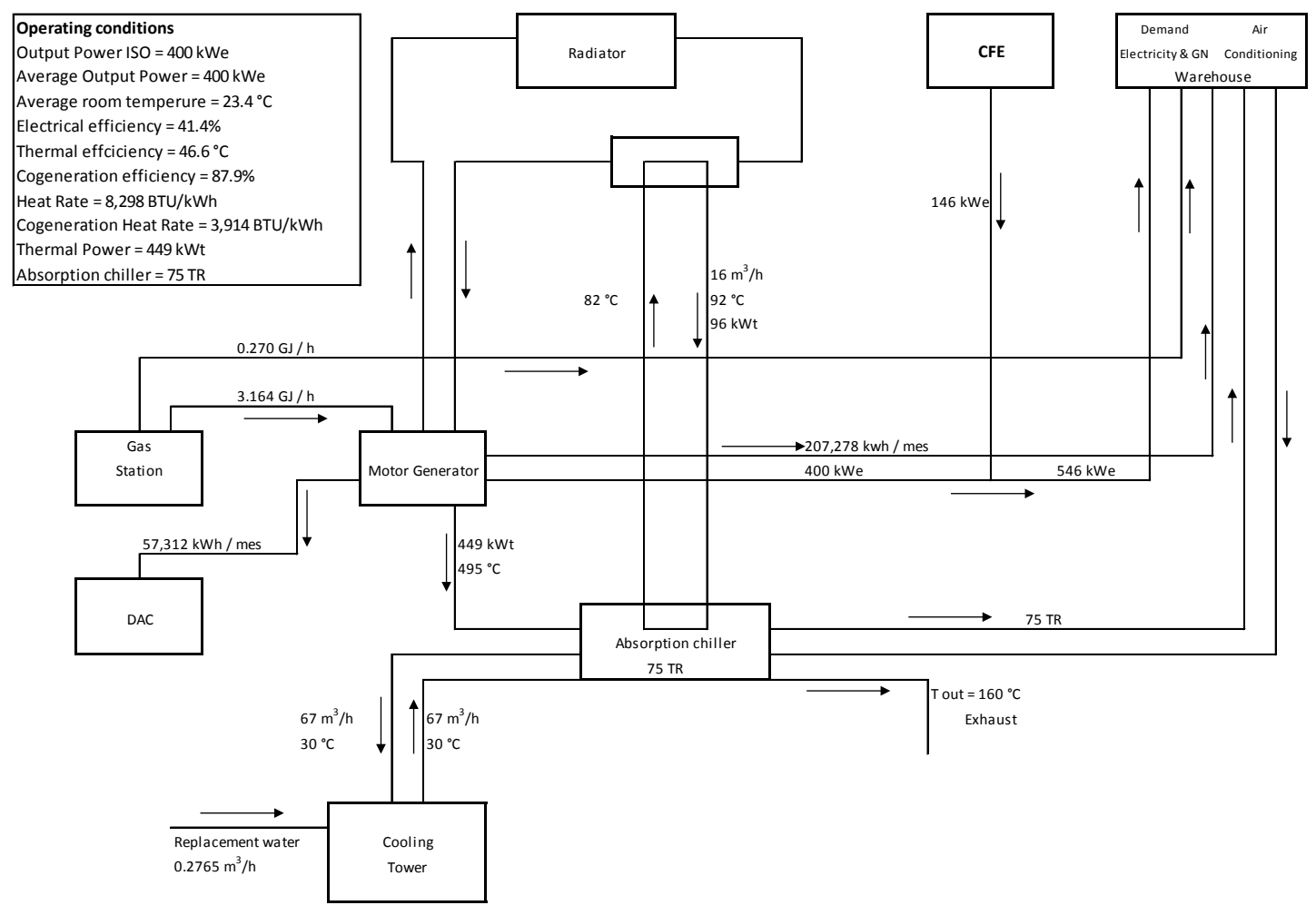

Fig. 4. General cogeneration system scheme.

Regarding the energetic performance of the motor generator, it was observed that the total energy produced per year is higher than the energy that is currently consumed (Table 9). However, the demands (base, intermediate, and peak) of the warehouse (kWe) are higher than the installed capacity that has been proposed (Table 10). In this case, the lacking demand would be supplied by CFE.

The calculation of the new billable demand (DF, for its initials in Spanish) was obtained using expression (1):

$$
D F=D P+F R I \times \max (D I-D P, 0)+F R B \times \max (D B-D P I, 0)
$$

where:

$\mathrm{DP}$ is the average maximum demand during the peak period

DI is the average maximum demand during the intermediate period
DB is the average maximum demand during the base period

DPI is the average maximum demand during the peak and intermediate periods

FRI and FRB are reduction factors with values of 0.150 and 0.300 , respectively 


\section{TABLE 9}

COGENERATION SYSTEM PERFORMANCE

\begin{tabular}{|c|c|c|c|c|c|c|c|c|c|}
\hline \multirow[t]{2}{*}{ Month } & \multicolumn{4}{|c|}{ Demand $(\mathrm{kW})$} & \multicolumn{3}{|c|}{ Energy produced $(\mathrm{kWh})$} & \multirow[b]{2}{*}{$\begin{array}{l}\text { TOTAL } \\
\text { produced }\end{array}$} & \multirow{2}{*}{$\begin{array}{l}\text { Current } \\
\text { e nergy } \\
\text { consumed }\end{array}$} \\
\hline & Base & Int & Peak & Billable & Base & Int & Peak & & \\
\hline January & 400 & 400 & 400 & 400 & 70,680 & 164,920 & 47,120 & 282,720 & 215,940 \\
\hline February & 400 & 400 & 400 & 400 & 63,840 & 148,960 & 42,560 & 255,360 & 198,166 \\
\hline March & 400 & 200 & 200 & 230 & 70,680 & 104,160 & 29,760 & 204,600 & 212,164 \\
\hline April & 400 & 400 & 400 & 400 & 68,400 & 182,400 & 22,800 & 273,600 & 246,737 \\
\hline May & 400 & 400 & 400 & 400 & 70,680 & 188,480 & 23,560 & 282,720 & 248,144 \\
\hline June & 400 & 400 & 400 & 400 & 68,400 & 182,400 & 22,800 & 273,600 & 241,658 \\
\hline July & 400 & 400 & 400 & 400 & 70,680 & 188,480 & 23,560 & 282,720 & 257,412 \\
\hline August & 400 & 400 & 400 & 400 & 70,680 & 188,480 & 23,560 & 282,720 & 256,795 \\
\hline September & 400 & 400 & 400 & 400 & 68,400 & 182,400 & 22,800 & 273,600 & 242,070 \\
\hline October & 400 & 400 & 400 & 400 & 70,680 & 188,480 & 23,560 & 282,720 & 250,636 \\
\hline November & 400 & 200 & 200 & 230 & 68,400 & 100,800 & 28,800 & 198,000 & 223,072 \\
\hline December & 400 & 400 & 400 & 400 & 70,680 & 164,920 & 47,120 & 282,720 & 224,636 \\
\hline Minimum & 400 & 200 & 200 & 230 & 63,840 & 100,800 & 22,800 & 198,000 & 198,166 \\
\hline Maximum & 400 & 400 & 400 & 400 & 70,680 & 188,480 & 47,120 & 282,720 & 257,412 \\
\hline Average & 400 & 367 & 367 & 372 & 69,350 & 165,407 & 29,833 & 264,590 & 234,786 \\
\hline TOTAL & & & & & & & & $3,175,080$ & $2,817,430$ \\
\hline
\end{tabular}

TABLE 10

ENERGY AND DEMAND ASSESSMENT

\begin{tabular}{lllllllll}
\hline & \multicolumn{4}{c}{ Demand $(\mathbf{k W})$} & \multicolumn{4}{c}{ Energy produced (kWh) } \\
\hline \multicolumn{1}{c}{ Month } & Base & Int & Peak & Billiable & Base & Int & Peak & Total \\
\hline January & 65 & 84 & - & 26 & $-13,886$ & $-37,374$ & $-15,520$ & $-66,780$ \\
February & 66 & 44 & 4 & 20 & $-12,342$ & $-31,884$ & $-12,968$ & $-57,194$ \\
March & 73 & 307 & 275 & 285 & $-15,310$ & 21,261 & 1,613 & 7,564 \\
April & 194 & 97 & 146 & 154 & $-12,442$ & $-46,459$ & 32,038 & $-26,863$ \\
May & 221 & 119 & 169 & 177 & 490 & $-39,064$ & 3,998 & $-34,576$ \\
June & 242 & 147 & 94 & 125 & 39,611 & $-62,012$ & $-9,542$ & $-31,942$ \\
July & 235 & 112 & 165 & 176 & $-6,029$ & $-22,835$ & 3,556 & $-25,308$ \\
August & 220 & 95 & 148 & 160 & -364 & $-28,273$ & 2,712 & $-25,925$ \\
September & 183 & 115 & 164 & 167 & $-3,378$ & $-31,827$ & 3,674 & $-31,530$ \\
October & 204 & 70 & 119 & 132 & $-9,646$ & $-52,378$ & 29,940 & $-32,084$ \\
November & 98 & 367 & 239 & 278 & $-13,526$ & 33,721 & 4,877 & 25,072 \\
December & 29 & 121 & 13 & 46 & $-20,985$ & $-24,720$ & $-12,379$ & $-58,084$ \\
\hline Minimum & 29 & 44 & - & 20 & $-20,985$ & $-62,012$ & $-15,520$ & $-66,780$ \\
Maximum & 242 & 367 & 275 & 285 & 39,611 & 33,721 & 32,038 & 25,072 \\
Average & 153 & 140 & 128 & 146 & $-5,651$ & $-26,820$ & 2,667 & $-29,804$ \\
\hline TOTAL & 1,830 & 1,678 & 1,535 & 1,746 & $-67,807$ & $-321,844$ & 32,001 & $-357,650$ \\
\hline
\end{tabular}

Note: The negative red numbers indicate energy surpluses. 
Table 11 summarizes the warehouse potential consumption of natural gas, including the consumption of the proposed motor generator.

TABLe 11

NATURAL GAS CONSUMPTION IN THE WAREHOUSE

\begin{tabular}{|c|c|c|c|c|}
\hline Month & $\begin{array}{l}\text { Warehouse } \\
\text { (GJ) }\end{array}$ & $\begin{array}{l}\text { GN MCI } \\
\text { (GJ) }\end{array}$ & $\begin{array}{c}\text { Total GN } \\
\text { (GJ) }\end{array}$ & $\begin{array}{c}\text { Air } \\
\text { conditioning } \\
\text { (TR) }\end{array}$ \\
\hline January & 201 & 2475 & 2676 & 0 \\
\hline February & 240 & 2236 & 2476 & 0 \\
\hline March & 221 & 1791 & 2012 & 75 \\
\hline April & 213 & 2395 & 2608 & 75 \\
\hline May & 218 & 2475 & 2693 & 75 \\
\hline June & 182 & 2395 & 2577 & 75 \\
\hline July & 207 & 2475 & 2682 & 75 \\
\hline August & 192 & 2475 & 2667 & 75 \\
\hline September & 172 & 2395 & 2567 & 75 \\
\hline October & 186 & 2475 & 2661 & 75 \\
\hline November & 176 & 1733 & 1909 & 0 \\
\hline December & 159 & 2475 & 2634 & 0 \\
\hline Minimum & 159 & 1,733 & 1,909 & 75 \\
\hline Maximum & 240 & 2,475 & 2,693 & 75 \\
\hline Average & 197 & 2,316 & 2,514 & 75 \\
\hline TOTAL & 2,367 & 27,796 & 30,163 & --- \\
\hline
\end{tabular}

\section{Simple cost-benefit analysis}

Based on the knowledge of current savings and consumption, a simple cost-benefit analysis was carried out for the period of the technical-financial proposal. To do this, it was necessary to identify the market prices of the different equipment and categories considered for this project (Table 12), including the cost of the equipment units and their complete installation. The latter entails interconnections, auxiliary equipment, adaptations, the civil engineering project, maneuvering, installation, and implementation. The average prices of consumables, the DAC rate, and the maintenance costs per kilowatt generated were also considered (Table 13).
TABLE 12

\begin{tabular}{|c|c|}
\hline \multicolumn{2}{|c|}{ ANTICIPATED FINANCIAL INVESTMENT } \\
\hline Equipment & $\begin{array}{c}\text { Investment cost in } \\
\text { USD }\end{array}$ \\
\hline Motor generator $(400 \mathrm{kWe})$ & 454,580 \\
\hline $\begin{array}{l}\text { Installation of motor } \\
\text { generator }\end{array}$ & 391,860 \\
\hline Absorption chiller & 160,000 \\
\hline $\begin{array}{l}\text { Installation of absorption } \\
\text { chiller }\end{array}$ & 84,818 \\
\hline TOTAL & $1,091,258$ \\
\hline
\end{tabular}


TABle 13

COSTS CONSIDERED FOR THE FINANCIAL

\begin{tabular}{lll}
\multicolumn{3}{c}{ SAVINGS EVALUATION } \\
\hline Item & $\begin{array}{l}\text { Cost } \\
\text { (USD) }\end{array}$ & Unit \\
\hline Water & 2.96 & $\mathrm{~m}^{3}$ \\
Natural Gas & 0.1784 & $\mathrm{~m}^{3}$ \\
Electricity & 0.1128 & $\mathrm{kWh}$ \\
DAC rate & 0.240 & $\mathrm{kWh}$ \\
Sales price for DAC users & 0.216 & $\mathrm{kWh}$ \\
Billable demand (DF) & 18.461 & $\mathrm{~kW}$ \\
Maintenance & 0.011 & $\mathrm{kWh}$ generated \\
\hline
\end{tabular}

When assessing the consumption and savings according to the proposal, we considered the increase in water consumption (459 USD per month) and natural gas (11,350 USD per month). Furthermore, changing airconditioning technology generates savings in energy consumption $(27,508 \mathrm{kWh}$ per month), which should be added to the surplus of electrical energy $(29,804$ $\mathrm{kWh}$ per month). The per item DF savings should be considered as the average monthly capacity of the motor generator $(372 \mathrm{~kW})$, with an average remaining billable demand deficit of $146 \mathrm{~kW}$ per month to be paid (Table 14).

\section{TABLE 14}

CoST-BENEFIT ANALYSIS

\begin{tabular}{lllll}
\hline Item & $\begin{array}{l}\text { Average variable } \\
\text { per month }\end{array}$ & Unit & $\begin{array}{l}\text { Cost } \\
\text { USD }\end{array}$ & $\begin{array}{l}\text { Profit } \\
\text { USD }\end{array}$ \\
\hline Energy & 234,786 & $\mathrm{kWh}$ & & 26,484 \\
Profit from energy sales $(D A C)$ & 57,312 & $\mathrm{kWh}$ & & 12,379 \\
Increase in water & 155 & $\mathrm{~m}^{3}$ & 459 & \\
Increase in natural gas & 2,195 & $\mathrm{MMBTU}$ & 11,350 & \\
Current $D F$ costs & 512 & $\mathrm{~kW}$ & & $(9,452)$ \\
Proposed $D F$ costs & 146 & $\mathrm{~kW}$ & $(2,695)$ & \\
Maintenance costs & 264,590 & $\mathrm{kWh}$ & 2,910 & \\
Benefit from $D F$ & 372 & $\mathrm{~kW}$ & & 6,757 \\
TOTAL monthly benefit & & & & 30,901 \\
TOTAL investment & & & \multicolumn{2}{l}{$1,091,258$} \\
CB & & & 2.9 years & \\
\hline
\end{tabular}

The investment payback period for this project is 2.9 years, which makes it an attractive project with outstanding advantages that benefit the company performance directly regardless of the CFE rates. Likewise, it guarantees the quality of energy inside the warehouse, thus promoting energy savings.

This project could cover $100 \%$ of the electrical energy that is consumed by the warehouse

$\left(207,278 \mathrm{kWh} \mathrm{month}^{-1}\right)$, in addition to transporting $57,312 \mathrm{kWh}$ per month at a rate of $10 \%$ below the DAC cost. Three air-conditioning equipment packages would be substituted by an absorption chiller, which consumes $54 \%$ less electrical energy.

\section{Conclusion}

The proposed cogeneration system conformed of a motor generator and an absorption cooling equipment proved to be an adequate, viable, and technically feasible option for a warehouse. Moreover, the investment payback period for this project is very attractive, as the total cost of the project would be covered in less than three years, including maintenance costs. The cogeneration systems can be applied to both large or industrial companies that have significant levels of electrical and thermal energy consumption, and to small service-provider companies -as was demonstrated-, as long as they have the necessary primary inputs. 


\section{Nomenclature}

$\begin{array}{ll}\text { CC } & \text { Connected load }(\mathrm{kW}) \\ \text { DF } & \text { Billable demand }(\mathrm{KW}) \\ \text { FP } & \text { Power factor }(\%) \\ \text { FC } & \text { Load factor }(\%) \\ \text { TR } & \text { Tons of refrigeration } \\ \text { COP } & \text { Coefficient of performance } \\ \text { T } & \text { Temperature }\left({ }^{\circ} \mathrm{C}\right) \\ \text { GN } & \text { Natural gas } \\ \text { GJ } & \text { Giga Joules }\end{array}$

\section{REFERENCES}

[1] S. M. Soler-Pérez, "Metodología general para la evaluación integral de la eficiencia energética en los centrales azucareros," Tecnología Química, vol. 31 (1), pp. 40-46, 2011.

[2] Conuee and Giz, "Manual para la Implementación de un Sistema de Gestión de la Energía," 2nd. Ed., Conuee/Giz, México, 2016. Available in: http:// www.gob.mx/cms/uploads/attachment/file/119159/ Manual_SGEn_Conuee_2da_Edicion.compressed. pdf.

[3] H. T. Ramírez, and G. A. Monforte, "Eficiencia de las estrategias de uso eficiente de energía eléctrica en hoteles de cinco estrellas en la ciudad de Mérida, Yucatán," in XI Congreso internacional de investigación en ciencias administrativas, 2007.

[4] Calidad y Sustentabilidad en la Edificación A.C., "Código de la conservación de la energía para las Edificaciones en México," CASESI, México, 2016. Available in: http://www.casedi.org.mx/quienessomos/2-uncategorised.

[5] D. Staniaszek, and E. Lees, "Determining Energy Savings for Energy Efficiency Obligation Schemes," RAP, 2012.

$\begin{array}{ll}\mathrm{DC} & \text { Contract demand }(\mathrm{kW}) \\ \mathrm{CB} & \text { Investment payback period } \\ (\text { years }) & \\ \mathrm{DAC} & \text { High domestic consumption rate } \\ \left(\$ \mathrm{kWh}^{-1}\right) & \\ \mathrm{CFE} & \text { Comisión Federal de Electricidad } \\ \mathrm{MCI} & \text { Motor generador } \\ \mathrm{kWe} & \text { Electric kilowatt } \\ \mathrm{kWt} & \text { Thermal kilowatt } \\ \mathrm{USD} & \text { American dollar }\end{array}$

[6] M. A. Lozano, and J. Ramos, "Análisis energético y económico de sistemas simples de cogeneración," Información Técnica, vol. 18(5), pp. 75-84, 2007.

[7] DOF, "Resolución por la que la comisión reguladora de energía expide la metodología para el cálculo de la eficiencia de los sistemas de cogeneración de energía eléctrica y los criterios para determinar la "Cogeneración Eficiente"," México, 2011. Available in: http://www.cre.gob.mx/documento/2299.pdf

[8] M. F. Fernández, P. L. Huante, and C. A. Romo, "Sistemas de cogeneración," Boletín IIE, vol. 30 (2), pp. 67-72, 2006.

[9] E. V. Torres, P. M. Salazar, L. R. Lugo, and A. Torres, "Análisis exergoeconómico de una planta de cogeneración con turbina de gas considerando el proceso de formación del residuo", in CIBIM 10, Oporto, Portugal, 1387-1392, 2011.

[10] H. C. A. Orozco, "Ahorro de energía y eficiencia energética en sistemas de aire acondicionado y refrigeración," Scientia et Technica, vol. 10(24), pp. 127-132, 2004.

[11] F. Li, L. Duanmu, and X. L. Zhao, "Research and application of flue gas waste heat recovery in cogeneration based on absorption heat-exchange," Procedia Engineering, vol. 146, pp. 595-603, 2016. DOI: https://doi.org/10.1016/j.proeng.2016.06.407. 
